\begin{tabular}{|c|c|}
\hline \multirow{3}{*}{ 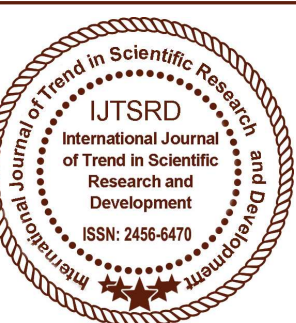 } & $\begin{array}{l}\text { International Journal of Trend in Scientific } \\
\text { Research and Development (IJTSRD) }\end{array}$ \\
\hline & International Open Access Journal \\
\hline & ISSN No: 2456 -6470 | www.ijtsrd.com | Volume - 2 | Issue - 3 \\
\hline
\end{tabular}

\title{
An Experimental Study on Shear Strength of Soil Subgrade using Cement as Stabilizing Agent
}

Ausif Hussain Dangroo

Desh Bhagat University, Mandi Gobindgrah, Punjab

\author{
Deepak Dalal \\ Assistant Professor, Desh Bhagat University, \\ Mandi Gobindgrah, Punjab
}

\section{INTRODUCTION}

\section{General}

Soil stabilization is the process of altering some soil properties by different methods, mechanical or chemical in order to produce an improved soil material which has all the desired engineering properties. Soils are generally stabilized to increase their strength and durability or to prevent erosion and dust formation in soils. The main aim is the creation of a soil material or system that will hold under the design use conditions and for the designed life of the engineering project. The properties of soil vary a great deal at different places or in certain cases even at one place; the success of soil stabilization depends on soil testing. Various methods are employed to stabilize soil and the method should be verified in the lab with the soil material before applying it on the field. The objective of soil stabilization is to improve the California Bearing Ratio of in-situ soils by 4 to 6 times. The other prime objective of soil stabilization is to improve on-site materials to create a solid and strong sub-base and base courses. In certain regions of the world, typically developing countries and now more frequently in developed countries, soil stabilization stabilization is to improve on-site materials to create a solid and strong sub-base and base courses. In certain regions of the world, typically developing countries and now more frequently in developed countries, soil stabilization is being used to construct the entire road.

In the past, soil stabilization was done by utilizing the binding properties of clay soils, cement-based products such as soil cement utilizing the "rammed earth" technique (compaction) and lime.
Traditionally and widely accepted types of soil stabilization techniques use products such as bitumen emulsions which can be used as a binding agents for producing a road base. However, bitumen is not environmentally friendly and becomes brittle when it dries out. Portland cement has been used as an alternative to soil stabilization. However, this can often be expensive and is not a very good "green" alternative.

\section{Scope of Study}

The scope is to improving the engineering properties of soils used for pavement base courses, sub base courses, and sub grades by the use of additives which are mixed into the soil to effect the desired improvement. These criteria are also applicable to roads and airfields having a stabilized surface layer. As we know Soil-cement highly-compacted mixture of soil, Portland cement, and water. As the cement reacts, or hydrates, the mixture gains strength and improves the engineering properties of the raw soil. Its improved strength and durability, combined with its low first cost and ease of construction, make soilcement an outstanding value for use as a base and sub base material. Its improved strength and durability, combined with its low first cost and ease of construction, make soil-cement an outstanding value for use as a base and sub base material. The soil material in soil-cement can be almost any combination of sand, silt, clay, shell, gravel, or crushed stone. Soil-cement is often more economical to construct than granular bases through the use of soil material on or near the commercial paving site. 
Modern methods and equipment make soil-cement processing simple and efficient. soils are processed at the paving site. When borrow soil is used, it is usually mixed in a central plant at the borrow source, then hauled to the paving site to be compacted, finished to grade, and cured. There is no mellowing period or other delays in the construction process. In addition, soil-cement is stable immediately after construction and gains strength rapidly. Making good soil-cement out of old flexible pavement is nothing new; it has been done for years. Failed flexible pavements contain materials that can be salvaged economically by recycling - breaking them up, pulverizing them, and stabilizing them with a minimum quantity of Portland cement to make a new soil-cement base. There is no disposal problem as is commonly found when old pavements are dug out. Since approximately $90 \%$ of the material used is already in place, handling and hauling costs are cut to a minimum. Many granular and waste materials from quarries and gravel pits can also be used to make soil-cement, thus conserving high-grade materials for other purposes. Soil-cement is often more economical to construct than granular bases through the use of soil material on or near the commercial paving site. Generally, any in-place nonorganic, low plasticity soils can be used. Also, nearby granular borrow soil can provide an excellent material source, requiring lower cement contents than clay and silt soils. Borrow soils do not have to be expensive base-course material; almost any granular material is suitable.

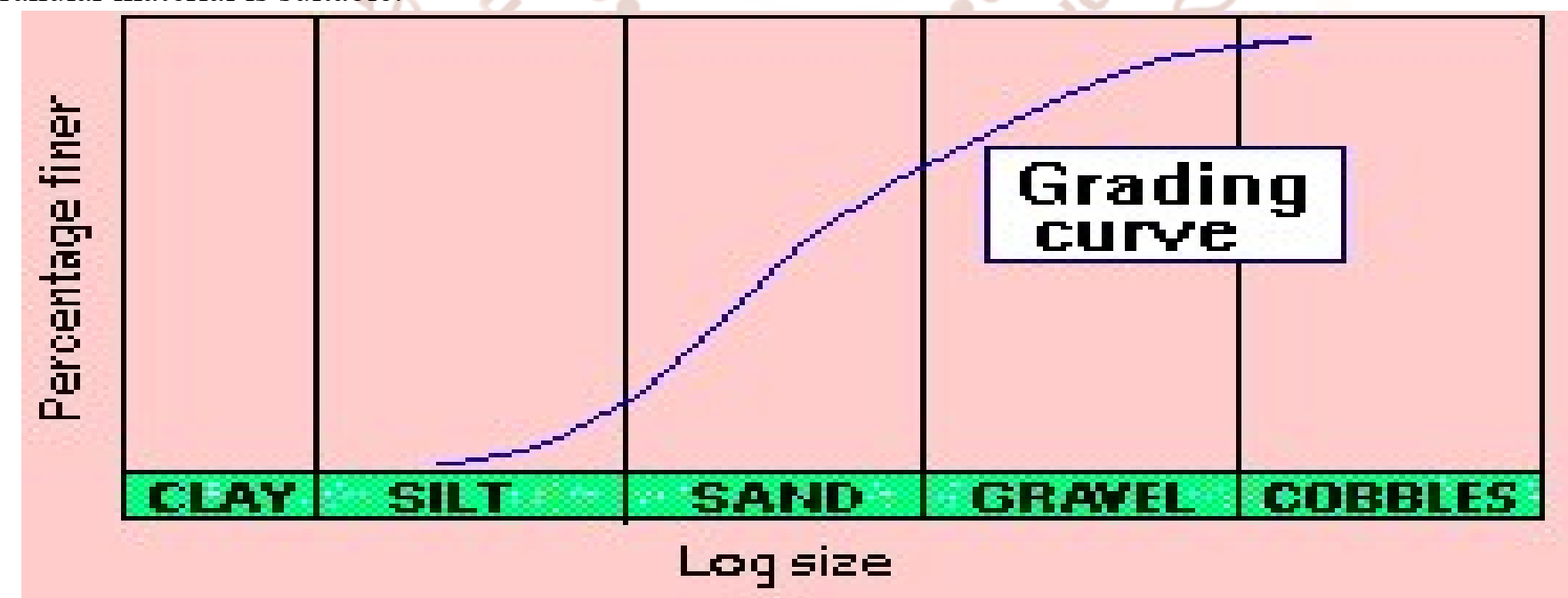

\section{EXPERIMENTAL INVESTIGATIONS}

\section{Scope of work}

The experimental work comprises in the following parts:

1. Particle size distribution by sieve analysis

2. Determination of the maximum dry density (MDD) and the corresponding optimum moisture content (OMC) of the soil by Proctor compaction test.

\section{Grain size distribution by sieve analysis:-}

Test for the grain size distribution is carried out by sieve analysis by using a set of standard sieves The panicle size distribution of soils can be performed by two methods, i.e. sieve analysis and hydro-meter analysis. If more than $50 \%$ of the soil sample passes through $75 \mathrm{micron}$, then the particle size analysis is done by hydro-meter method but if the percentage of the particles retained on the $75 \mathrm{micron}$ is more than the percentile of the particles passing through it, therefore the panicle size distribution is determined by sieve analysis.

The size distribution curves, as obtained from coarse and fine grained portions, can be combined to form one complete grain-size distribution curve (also known as grading curve). A typical grading curve is shown.

\section{Grading curve}

From the complete grain-size distribution curve, useful information can be obtained such as: 
2). Percentages (or fractions) of gravel, sand, silt and clay-size
A grading curve is a useful aid to soil description. The geometric properties of a grading curve are called grading characteristics.

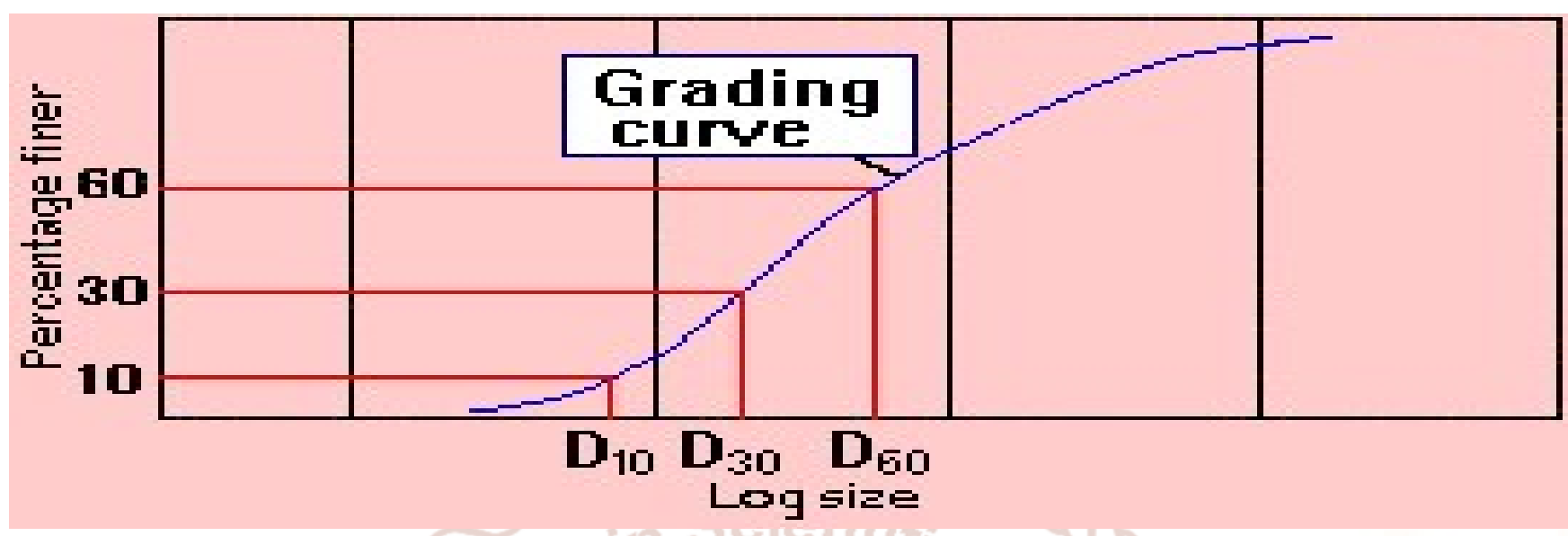

\section{Grading Characteristics}

To obtain the grading characteristics, three points are located first on the grading curve for calculating Cc and $\mathrm{Cu}$. The following panicle classification names are given depending on the size of the particles:

- Boulders: Particle size is more than $300 \mathrm{~mm}$.

- Cobble: Particles size range $80 \mathrm{~mm}$ to $300 \mathrm{~mm}$,

- Gravel: Particles size in range 4.75 to $80 \mathrm{~mm}$

- Coarse Gravel: $20 \mathrm{~mm}$ to $80 \mathrm{~mm}$.

- Fine Gravel: $4.75 \mathrm{~mm}$ to $20 \mathrm{~mm}$

- Sand: Particles size in range $0.075 \mathrm{~mm}$ to $4.75 \mathrm{~mm}$.

- Coarse sand: $2.0 \mathrm{~mm}$ to $4.75 \mathrm{~mm}$.

- Medium Sand: $0.075 \mathrm{~mm}$ to $0.425 \mathrm{~mm}$.

- Fine Sand: $0.075 \mathrm{~mm}$ to $0.425 \mathrm{~mm}$.

Soils having Less than $50 \%$ particles of size smaller than $0.075 \mathrm{~mm}$ are designated by the symbols as:

- Poorly Graded Gravel (GP).

- Well Graded Gravel. (OW)

- Well Graded Sand. (SW)

- Poorly Graded Sand (SP)
Gravels and sands may be either poorly graded (uniformly graded) or well graded depending on the value of coefficient of curvature and uniformity coefficient. Coefficient of curvature (Cc) may be estimated as:

$$
\mathrm{Cc}=\frac{\mathrm{D} 30^{2}}{D 10 \times D 60}
$$

Coefficient of curvature should lie between 1 and 3 for well grade gravel and sand.

Uniformity coefficient $(\mathrm{Cu})$ is given by:

$$
\mathrm{Cu}=\frac{\mathrm{D} 60}{D 10} \text {. }
$$

Its value should be more than 4 for well graded gravel and more than 6 for well graded sand. Where, D60 $=$ Particle size at $60 \%$ finer.

D30 $=$ Particle size at 30\% finer.

D10 $=$ Particle size at $10 \%$ finer.

\section{For sand}

\begin{tabular}{|l|l|}
\hline GW( well graded Sand) & Having $\mathrm{Cc}=1$ to 3 and $\mathrm{Cu}>6$ \\
\hline GP(poorly graded sand) & $\begin{array}{l}\text { If it does not show the above two values i.e Cc } \\
\text { and } \mathrm{Cu} .\end{array}$ \\
\hline GM (Silty sand) & $\begin{array}{l}\text { When it lies below the Attenberg's Line and } \\
\text { having plasticity Index (Ip }<4)\end{array}$ \\
\hline GC (clayey sand) & $\begin{array}{l}\text { When it lies above the Attenberg's line and } \\
\text { having plasticity index (Ip }>7)\end{array}$ \\
\hline
\end{tabular}




\section{For gravel}

\begin{tabular}{|l|l|}
\hline GW( well graded gravel) & Having $\mathrm{Cc}=1$ to 3 and $\mathrm{Cu}>4$ \\
\hline GP(poorly graded gravel) & If it does not show the above two values i.e. $\mathrm{Cc}$ and $\mathrm{Cu}$. \\
\hline GM (Silty gravel ) & $\begin{array}{l}\text { When it lies below the Attenberg's Line and having plasticity } \\
\text { Index (Ip }<4)\end{array}$ \\
\hline GC (clayey gravel) & $\begin{array}{l}\text { When it lies above the Attenberg's line and having plasticity } \\
\text { index (Ip }>7)\end{array}$ \\
\hline
\end{tabular}

The grain sizes analysis is an attempt to determine the relative properties of the different grain sizes that makeup the soil sample. And also measurement of the proportion of the various primary soil particles as determined usually either by their capacities to pass through sieves of various mesh size or by rates of settling in water. The grain size analysis or particle size analysis is widely used in classification of soils. The data obtained from grain size distribution curve, is used in the design of filters earth dams and to determine suitability of soil for road construction, air field etc. Information obtained from grain size analysis can be used to predict soil water movement although permeability tests are more generally used.

The size distribution is often of critical importance to the way the material performs in use. A sieve analysis can be performed on any type of nonorganic or organic granular materials including sands, crushed rock, clays, granite, feldspars, coal, and soil, a wide range of manufactured powders, grain and seeds, down to a minimum size depending on Ac exact method. Being such a simple technique of particle sizing, it is probably the most common.

\section{OBSERVATION AND CALCULATION TABLE:}

Mass of soil Sample taken for Analysis $=500 \mathrm{~g}$.

\section{Sieve Analysis}

\begin{tabular}{|c|c|c|c|c|}
\hline Sieve size & $\begin{array}{l}\text { Mass of soil } \\
\text { retained } \\
(\mathrm{X})\end{array}$ & $\begin{array}{l}\% \text { of soil } \\
\text { retained } \\
\mathrm{Y} 1=\mathrm{X} / \mathrm{M}\end{array}$ & $\begin{array}{l}\text { Cumulative } \% \text { of soil } \\
\text { retained }(\%) \\
\mathrm{P} 1=\mathrm{Y} 1, \mathrm{P} 2=\mathrm{Y} 1+\mathrm{Y} 2\end{array}$ & $\begin{array}{l}\text { \% Finer } \\
=(100-\mathrm{P})\end{array}$ \\
\hline $4.75 \mathrm{~mm}$ & 0 & & $0+200$ & $100 \%$ \\
\hline $2 \mathrm{~mm}$ & $22 \mathrm{~g}$ & 4.42 & 4.42 & 95.58 \\
\hline 600 (micron) & $38 \mathrm{~g}$ & 7.63 & 12.05 & 87.95 \\
\hline 425 (micron) & $20 \mathrm{~g}$ & 4.02 & 16.07 & 83.93 \\
\hline 300 (micron) & $13 \mathrm{~g}$ & 2.60 & 18.67 & 81.33 \\
\hline 180(micron) & $146 \mathrm{~g}$ & 29.31 & 47.98 & 52.02 \\
\hline 75(micron) & $206 \mathrm{~g}$ & 41.36 & 89.34 & 10.66 \\
\hline Pan & $53 \mathrm{~g}$ & 10.64 & 99.98 & 0.02 \\
\hline
\end{tabular}




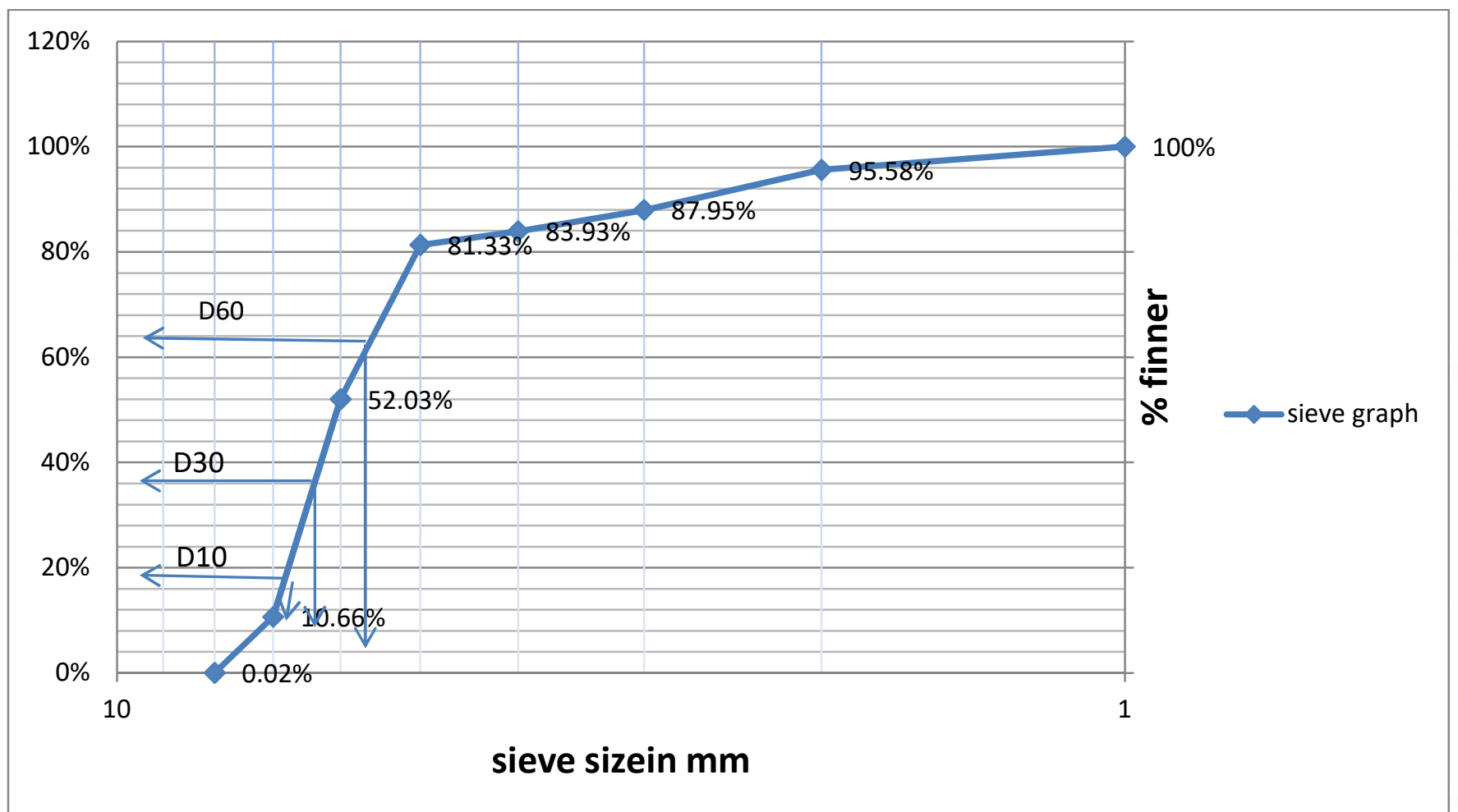

2. Determination of the maximum dry density (MDD) and the corresponding optimum moisture content (OMC) of the soil by Proctor compaction test.

In the construction of highway embankments, airports, earth. Dams and other engineering structures, the compaction of soils is needed to improve its increase i.e. to increase the unit weight. Compaction increases the strength characteristics soils, which increases the bearing capacity of the foundation constructed over them. Compaction also decreases the amount of the undesirable settlement of structures and increases the stability of slopes of the embankments. Therefore it is the artificial improvement of the mechanical properties of the soil. To assesses the degree of compaction, it is necessary to use the dry unit weight, which is an indicator of compactness of solid soil particles in a given volume.

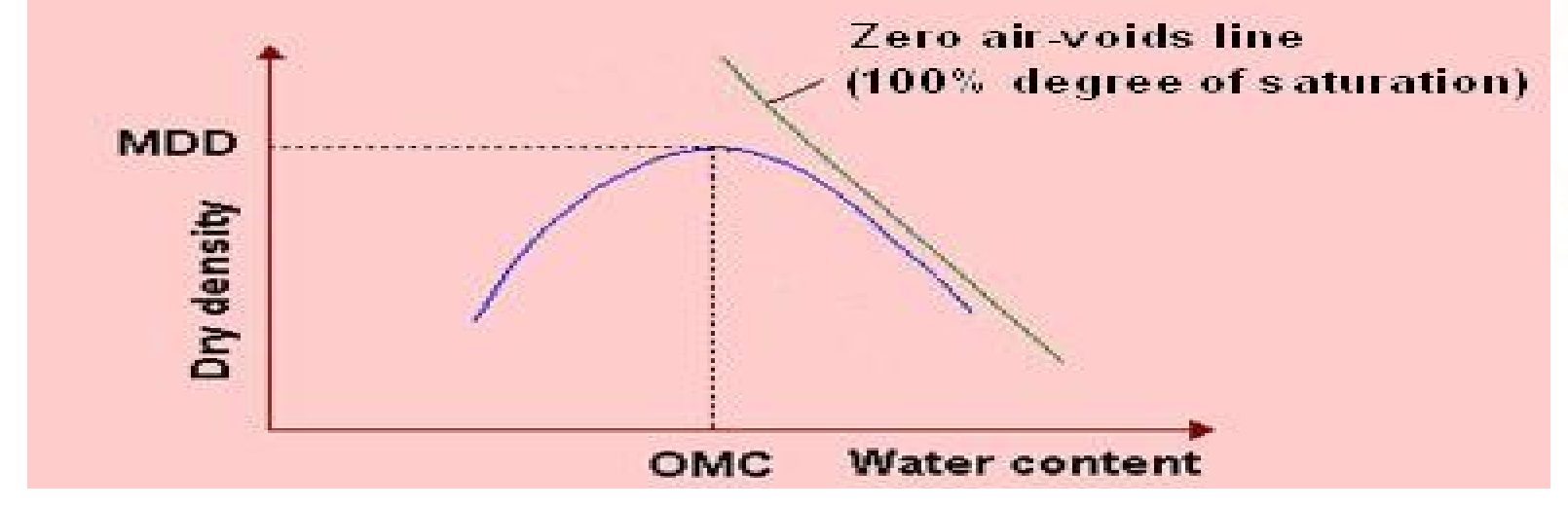

The laboratory testing is meant to establish the maximum dry density that can be attained for a given soil with a standard amount of compactive effort.

In the test, the dry density cannot be determined directly, and as such the bulk density and the moisture content are obtained first to calculate the

$$
\gamma_{d}=\frac{\gamma}{1+w}
$$

Where $\gamma=$ bulk density, and $\mathrm{w}=$ water content.

A series of samples of the soil are compacted at different water contents, and a curve is drawn with axes of dry density and water content. The resulting plot usually has a distinct peak as shown. Such inverted "V" curves are obtained for cohesive soils (or soils with fines), and are known as compaction curves. dry density as 


\section{Dry density related to water content and degree of saturation}

In 1993 Proctor developed a laboratory compaction test to determine the maximum dry density of compacted soils. In the compaction process the air content in the soil is reduced, decreasing the soil porosity as result of the soil densification (increase in the unit weight of the soil) without losing humidity. Therefore the resistance of the soil, the deformation capacity and permeability of the soil get affected resulting in inalterability against the external agents. These characteristics are modified due to the diminution of the void ratio produced by the soil densification. For coarse and fine-grained soils, average values are 8 to 15 and 17 to 36 respectively. Optimum moisture content is the moisture content that results in greatest density for specified compactive effort. The soil compacted at water contents higher than the optimum water content results in a relatively dispersed soil structure that is weaker, more ductile, less pervious, softer, more susceptible to shrinking, and less susceptible to swelling than soil compacted dry of optimum to the same density. The soil compacted lower than the optimum water content typically results in a flocculated soil structure that has the opposite characteristics of the soil compacted wet of the optimum water content to the same density.

At OMC, the soil is broadly $90 \%$ saturated depending upon type of soil, meaning that about $10 \%$ of the void space is occupied by air.

In the proctor test, the soil is compacted in a mould that has a volume of $2248.43 \mathrm{~cm} 3$. The diameter and height of the mould is $15 \mathrm{~cm}$ and $12.73 \mathrm{~cm}$ respectively. The mould is attached to a base plate at the bottom and to an extension at the top. The soil is mixed with varying amounts of water and then compacted in three layers (light compaction) or five layers (heavy compaction) by the hammer that delivers 56 blows to each layer. The hammer has a mass of $2.5 \mathrm{~kg}$ and has a drop of $30.5 \mathrm{~cm}$

For each test, the moisture content of the compacted soil is determined in the laboratory. With the known moisture content, the dry unit weight can be calculated as:

$$
\gamma d=\gamma b /(1+w \%)
$$

Where $\mathrm{W}(\%)=$ percentage of moisture content.

$\mathrm{Yd}=$ dry density of the sample.

$\mathrm{Yb}=$ bulk density of the sample.

The value of yd determined from the above equation can be plotted against to the corresponding moisture contents to obtain the maximum dry unit weight and the optimum moisture content for the soil. For the given moisture content $(\mathrm{w})$ and the degree of saturation $\mathrm{S}$, the dry unit weight of the compaction can be calculated as follows:

$$
\text { Yd }=\text { Gs. } \gamma \mathbf{\gamma w} /(\mathbf{1}-\mathrm{e})
$$

Where Gs = Specific gravity of the soil.

$\gamma w=$ unit weight of water.

$\mathrm{e}=$ void ratio

\section{Observations and Calculations:}

1. Diameter of mould, $\mathrm{d}(\mathrm{cm})=15 \mathrm{~cm}$

2.Height of mould, $\mathrm{h}(\mathrm{cm})=12.73 \mathrm{~cm}$

3. Volume of mould, $\mathrm{V}\left(\mathrm{cm}^{3}\right)=2250 \mathrm{~cm}^{\wedge} 3$

4. Mass of mould, $\mathrm{W}(\mathrm{g})=5.710 \mathrm{~kg}$

5. Wt. of rammer $(\mathrm{kg})=2.5 \mathrm{~kg}$

6. No. of layers $=3$

7. No.of blows/layer $=56$

8. height of rammer $=31 \mathrm{~cm}$

\section{MMD \& OMC of Sample 1 (Soil)}

\begin{tabular}{|l|c|c|c|c|}
\hline Sample no. & 1 & 2 & 3 & 4 \\
\hline$\%$ of Water added Ww & $13 \%$ & $16 \%$ & $19 \%$ & $22 \%$ \\
\hline $\begin{array}{l}\text { Weight of mould }+ \\
\text { compacted soil(g) }\end{array}$ & 9946 & 10114 & 9958 & 9880 \\
\hline $\begin{array}{l}\text { Weight of compacted soil } \\
\text { W }\end{array}$ & 4236 & 4404 & 4248 & 4170 \\
\hline
\end{tabular}


International Journal of Trend in Scientific Research and Development (IJTSRD) ISSN: 2456-6470

\begin{tabular}{|l|c|c|c|c|}
\hline $\begin{array}{l}\text { Bulk density } \\
\frac{\mathrm{W}}{\mathrm{V} \text { of mould }}(\mathrm{g} / \mathrm{cc})\end{array}$ & 1.88 & 1.95 & 1.87 & 1.85 \\
\hline Dry density= $\frac{\text { Bulk density }}{1+\mathrm{w}}$ & 1.59 & 1.68 & 1.61 & 1.51 \\
\hline Water content & A & B & C & D \\
\hline Container no. & $86 \mathrm{~g}$ & $70 \mathrm{~g}$ & $66 \mathrm{~g}$ & $66 \mathrm{~g}$ \\
\hline Weight of wet soil W1 & $77 \mathrm{~g}$ & $60 \mathrm{~g}$ & $56 \mathrm{~g}$ & $55 \mathrm{~g}$ \\
\hline Weight of dry soil W2 & 12 & 16 & 18 & 20 \\
\hline $\begin{array}{l}\text { Water content } x= \\
\frac{\text { W1-W2 }}{\mathrm{W} 2} \mathrm{x} 100\end{array}$ & & & & \\
\hline
\end{tabular}

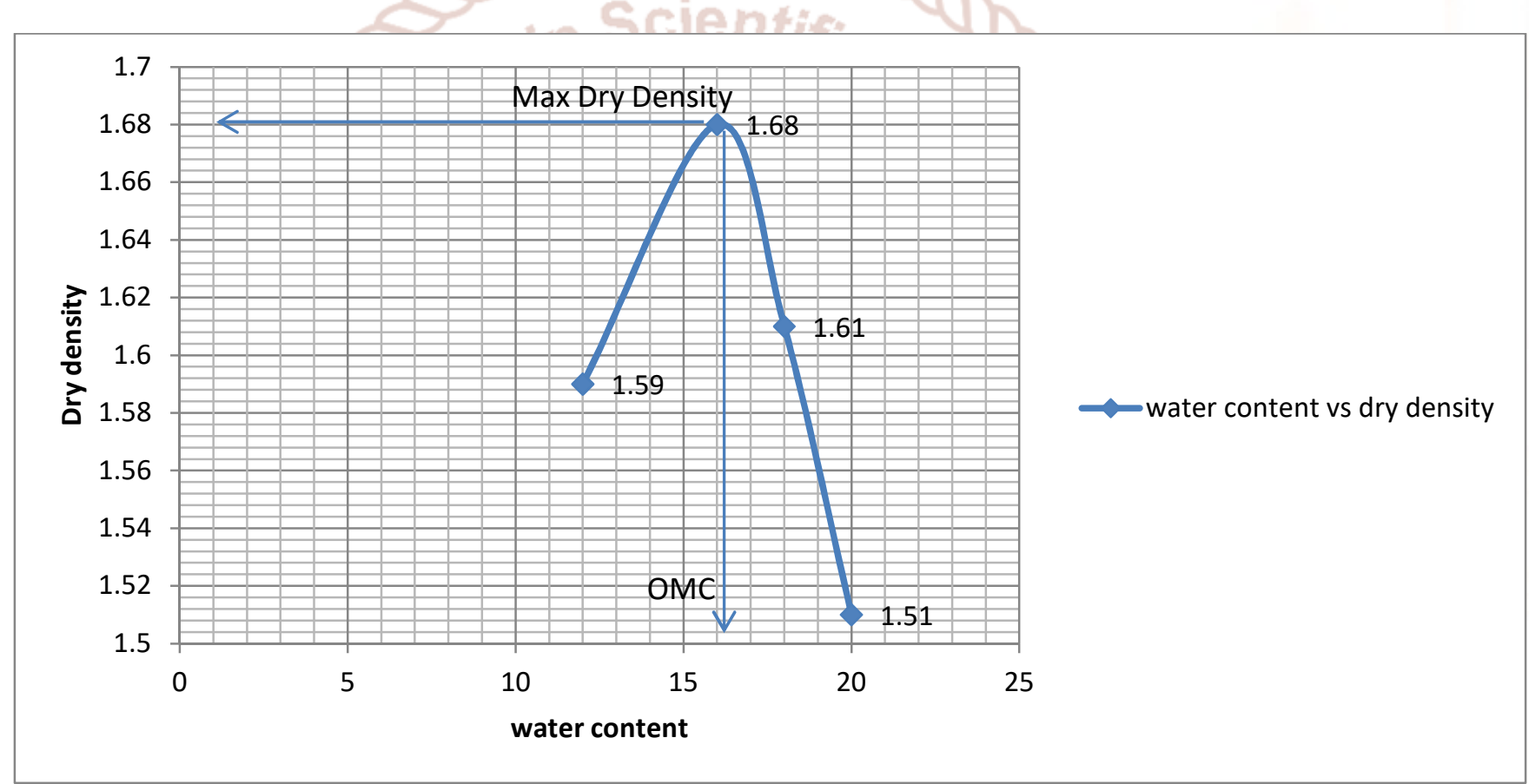

\section{Graph for sample 1(soil)}

\section{MMD \& OMC of Sample 2 by Adding 5\% of cement.}

In this we take $5 \mathrm{~kg}$ sample (I e $4.75 \mathrm{~kg}$ of soil $+.25 \mathrm{~kg}$ of cement)

\begin{tabular}{|l|c|c|c|c|}
\hline Sample no. & 1 & 2 & 3 & 4 \\
\hline$\%$ of Water added Ww & $13 \%$ & $16 \%$ & $19 \%$ & $22 \%$ \\
\hline $\begin{array}{l}\text { Weight of mould + } \\
\text { compacted soil(g) }\end{array}$ & 10146 & 11104 & 10102 & 9942 \\
\hline \begin{tabular}{l} 
Weight of compacted soil W \\
\hline $\begin{array}{l}\text { Bulk density } \\
\frac{\mathrm{w}}{\text { Vof mould }}(\mathrm{g} / \mathrm{cc})\end{array}$
\end{tabular} & 4026 & 4486 & 4438 & 4260 \\
\hline
\end{tabular}


International Journal of Trend in Scientific Research and Development (IJTSRD) ISSN: 2456-6470

\begin{tabular}{|l|c|c|c|c|}
\hline Dry density $=\frac{\text { Bulk density }}{1+\mathrm{w}}$ & 1.57 & 1.70 & 1.66 & 1.54 \\
\hline Water content & $\mathrm{A}$ & $\mathrm{B}$ & $\mathrm{C}$ & $\mathrm{D}$ \\
\hline Container no. & $88 \mathrm{~g}$ & $74 \mathrm{~g}$ & $68 \mathrm{~g}$ & $69 \mathrm{~g}$ \\
\hline Weight of wet soil W1 & $76 \mathrm{~g}$ & $62 \mathrm{~g}$ & $56 \mathrm{~g}$ & $54 \mathrm{~g}$ \\
\hline Weight of dry soil W2 & 16 & 19 & 21 & 28 \\
\hline $\begin{array}{l}\text { Water content } x=\frac{\mathrm{W} 1-\mathrm{W} 2}{\mathrm{~W} 2} \mathrm{x} \\
100\end{array}$ & & & \\
\hline
\end{tabular}

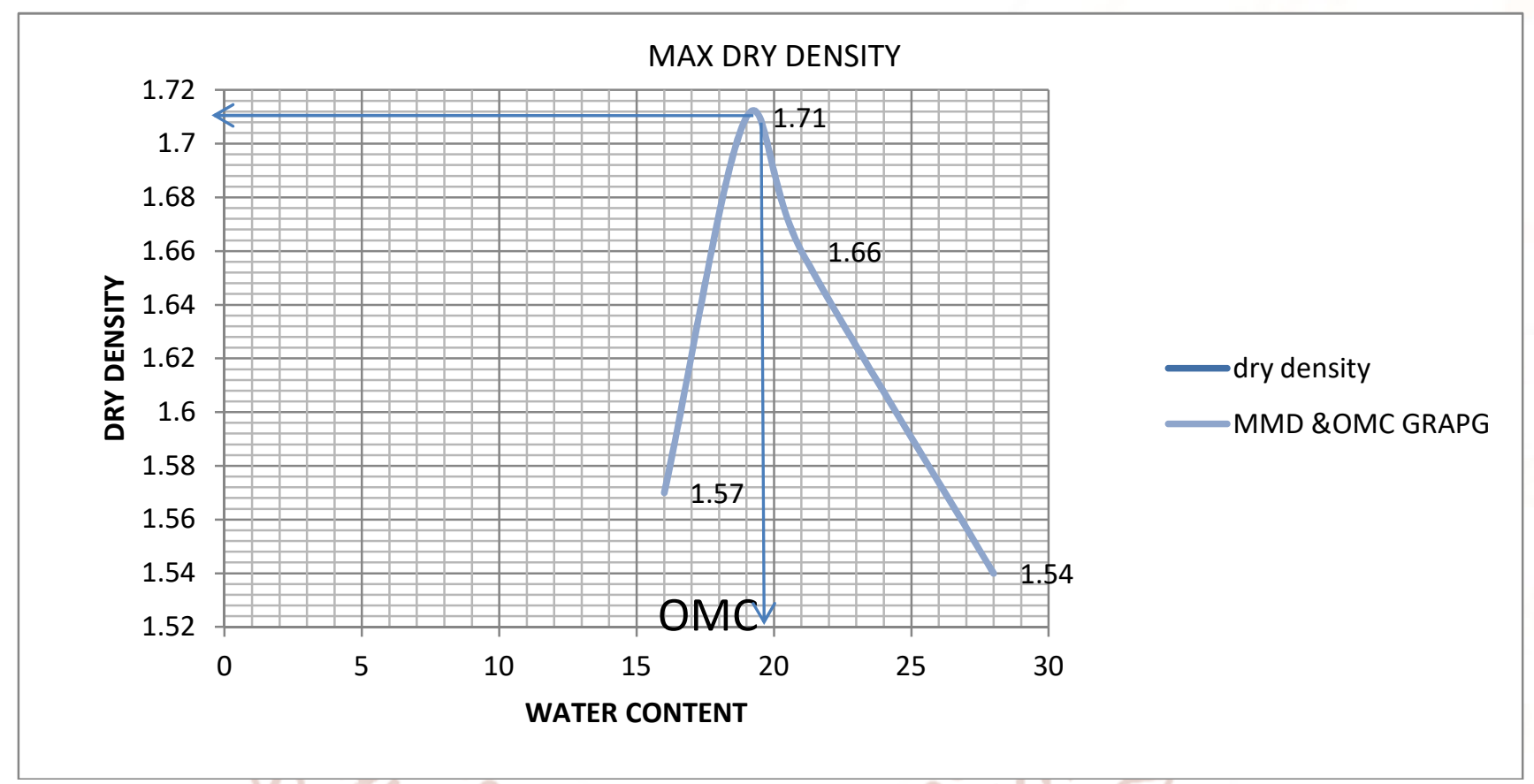

Graph for sample 2 by adding $5 \%$ of cement.

MMD and OMC of Sample 3 by Adding $10 \%$ of cement .

In this we take $5 \mathrm{~kg}$ sample that is $4.5 \mathrm{~kg}$ of soil $+.5 \mathrm{~kg}$ of cement

\begin{tabular}{|l|c|c|c|c|}
\hline \multicolumn{1}{|c|}{ Sample no. } & 1 & 2 & 3 & 4 \\
\hline$\%$ of Water added Ww & $13 \%$ & $16 \%$ & $19 \%$ & $22 \%$ \\
\hline $\begin{array}{l}\text { Weight of mould + } \\
\text { compacted sample }\end{array}$ & 10056 & 10146 & 9986 & 9880 \\
\hline $\begin{array}{l}\text { Weight of compacted } \\
\text { sample W }\end{array}$ & 4346 & 4436 & 4276 & 1.85 \\
\hline $\begin{array}{l}\text { Bulk density } \\
\left.\frac{\mathrm{W}}{\mathrm{V} \text { of mould }} \mathrm{g} / \mathrm{cc}\right)\end{array}$ & 1.93 & 1.97 & 1.90 & 1.51 \\
\hline $\begin{array}{l}\text { Dry density= Bulk density } \\
1+\mathrm{w}\end{array}$ & 1.70 & & 1.60 & \\
\hline
\end{tabular}


International Journal of Trend in Scientific Research and Development (IJTSRD) ISSN: 2456-6470

\begin{tabular}{|l|c|c|c|c|}
\hline Water content & A & B & C & D \\
\hline Container no. & $76 \mathrm{~g}$ & $56 \mathrm{~g}$ & $50 \mathrm{~g}$ & $53 \mathrm{~g}$ \\
\hline Weight of wet soil W1 & $68 \mathrm{~g}$ & $49 \mathrm{~g}$ & $43 \mathrm{~g}$ & $44 \mathrm{~g}$ \\
\hline Weight of dry soil W2 & 11.76 & 14.28 & 16.27 & 20.45 \\
\hline $\begin{array}{l}\text { Water content } x=\frac{\mathrm{W} 1-\mathrm{W} 2}{\mathrm{~W} 2} \mathrm{x} \\
100\end{array}$ & & & & \\
\hline
\end{tabular}

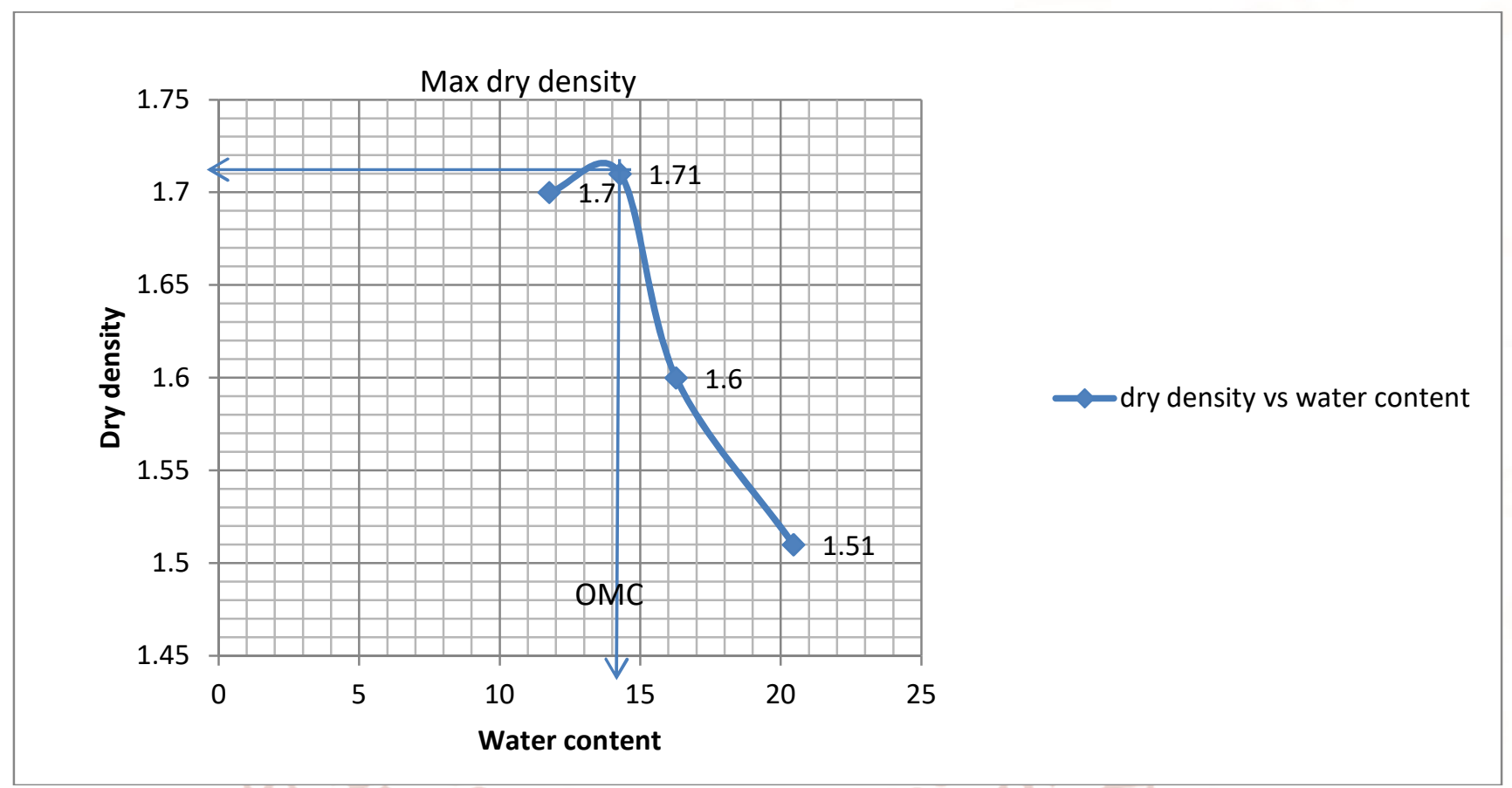

Graph for sample 3 by adding $10 \%$ of cement.

MMD \& OMC of Sample 4 by Adding 15\% of cement .

In this we take $5 \mathrm{~kg}$ sample (ie $4.25 \mathrm{~kg}$ of soil $+.75 \mathrm{~kg}$ of cement)

\begin{tabular}{|l|c|c|c|c|}
\hline Sample no. & 1 & 2 & 3 & 4 \\
\hline$\%$ of Water added Ww & $13 \%$ & $16 \%$ & $19 \%$ & $22 \%$ \\
\hline $\begin{array}{l}\text { Weight of mould + } \\
\text { compacted sample }\end{array}$ & 10256 & 11126 & 10112 & 9802 \\
\hline $\begin{array}{l}\text { Weight of compacted } \\
\text { sample W }\end{array}$ & 1.55 & 3648 & 3504 & 3401 \\
\hline $\begin{array}{l}\text { Bulk density } \\
\frac{\mathrm{W}}{\mathrm{V} \text { of mould }}(\mathrm{g} / \mathrm{cc})\end{array}$ & 1.37 & 1.39 & 1.52 & 1.52 \\
\hline \begin{tabular}{l} 
Dry density= $\frac{\text { Bulk density }}{1+\mathrm{w}}$ \\
\hline
\end{tabular} & & & 1.30 & \\
\hline
\end{tabular}


International Journal of Trend in Scientific Research and Development (IJTSRD) ISSN: 2456-6470

\begin{tabular}{|c|c|c|c|c|}
\hline \multicolumn{5}{|l|}{ Water content } \\
\hline Container no. & A & $\mathrm{B}$ & $\mathrm{C}$ & $\mathrm{D}$ \\
\hline Weight of wet soil W1 & $77 \mathrm{~g}$ & $58 \mathrm{~g}$ & $54 \mathrm{~g}$ & $51 \mathrm{~g}$ \\
\hline Weight of dry soil W2 & $68 \mathrm{~g}$ & $49 g$ & $44 \mathrm{~g}$ & $40 \mathrm{~g}$ \\
\hline $\begin{array}{l}\text { Water content } x=\frac{\mathrm{W} 1-\mathrm{W} 2}{\mathrm{~W} 2} \mathrm{x} \\
100\end{array}$ & 13.23 & 18.36 & 22.72 & 27.5 \\
\hline
\end{tabular}

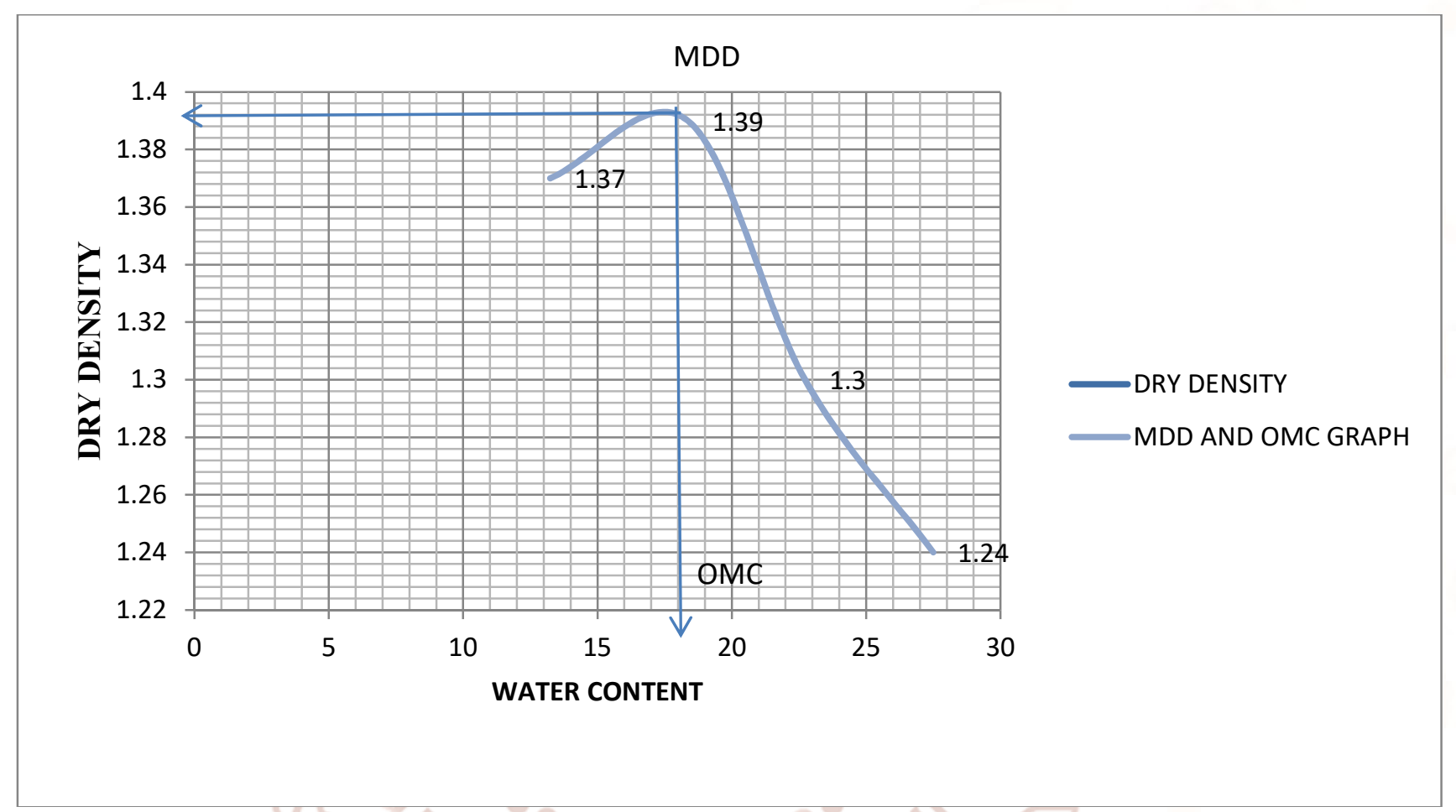

\section{Graph for sample 4 by adding $15 \%$ of cement}

\section{Max Dry Density vs. OMC}

\begin{tabular}{|l|l|l|l|l|}
\hline Result & Sample 1 (soil) & $\begin{array}{l}\text { Sample2 (soil + } \\
\text { cement) At 5\% }\end{array}$ & $\begin{array}{l}\text { Sample3 (soil + } \\
\text { cement) At 10\% }\end{array}$ & $\begin{array}{l}\text { Sample4 } \\
\text { cement) At 15\% }\end{array}$ \\
\hline Max dry density & $1.68 \mathrm{~g} / \mathrm{cc}$ & $1.70 \mathrm{~g} / \mathrm{cc}$ & $1.71 \mathrm{~g} / \mathrm{cc}$ & $1.39 \mathrm{~g} / \mathrm{cc}$ \\
\hline $\begin{array}{l}\text { Optimum moisture } \\
\text { content }\end{array}$ & $16 \%$ & $18 \%$ & $14.5 \%$ & 18.5 \\
\hline
\end{tabular}

Among the four soil samples being tested for the maximum dry density and the optimum moisture content. The sample 4 has the highest optimum moisture content but less maximum dry density and Samples 3 (soil +cement) has high maximum dry density but low moisture content. 


\section{CONCLUSION}

1. From Graphical representation of Sieve analysis (Fig 3.8) the coefficient of curvature (Cc) is found to be 1 and the coefficient of uniformity $(\mathrm{Cu})$ is 4. Based on the $\mathrm{Cc}$ and $\mathrm{Cu}$ we can conclude that the soil samples are sandy soil, consisting of sandy particles and some gravel.

2. Among the four soil samples being tested for the maximum dry density and the optimum moisture content, from the (Fig 3.20) and (Fig 3.13) it shows that the dry density and the optimum moisture content first increases when adding 5\% and $10 \%$ cement, then it goes on decreasing after adding $15 \%$ of cement to the soil due to shrinkage .The bearing capacity of any soil usually increases with increasing dry density and decreasing moisture content. High density assures high shear strength and greater imperviousness.

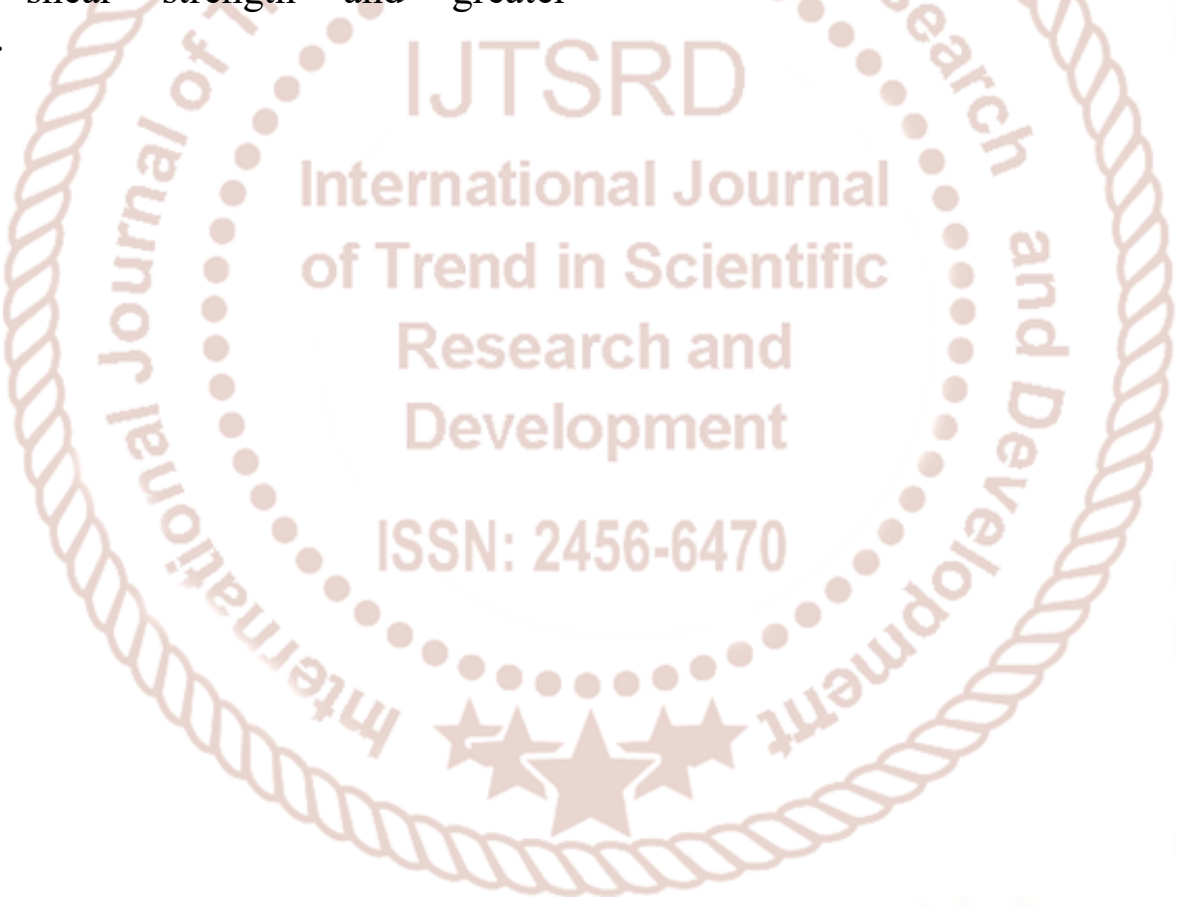

